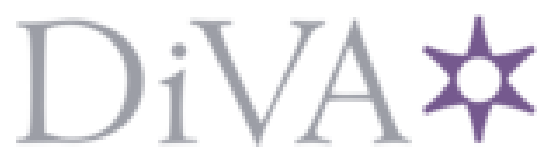

http://www.diva-portal.org

This is the published version of a paper published in International Journal of Cast Metals Research.

Citation for the original published paper (version of record):

Svidró, P., Diószegi, A. (2014)

On problems of volume change measurements in lamellar cast iron

International Journal of Cast Metals Research, 27(1): 26-37

https://doi.org/10.1179/1743133613Y.oooooooo75

Access to the published version may require subscription.

N.B. When citing this work, cite the original published paper.

Permanent link to this version:

http://urn.kb.se/resolve?urn=urn:nbn:se:kth:diva-225399 


\section{On problems of volume change measurements in lamellar cast iron}

\section{P. Svidró* and A. Diószegi}

Solidification of lamellar cast iron is a complex mechanism due to the contracting austenite phase and the expanding graphite phase precipitation. The combined effect of contraction-expansion has an influence on the volume change related defects (shrinkage porosity and penetration). Critical moments in measuring volume change are the methods used for measurement together with the interpretation of the solidification based on the macrostructure. Reliable results are obtained using displacement measurement in both axial and radial direction of a cylindrical sample in combination with using two thermocouples and a force measurement unit. Common drawback of the used method together with other methods presented in the literature is the early expansion observed before the coherence of the solidifying grains. The introduced force measurement gives a novel interpretation of the columnar to equiaxed transition, and the displacement measurement in different directions within a cast sample reveal the anisotropic character of the volume change.

Keywords: Volumetric change, Columnar to equiaxed transition, Lamellar cast iron

\section{Introduction}

Lamellar cast iron is one of the most important cast materials. This alloy is suitable for many applications because of its good mechanical and thermal properties and low production costs. Among many of the advantages, the tendency to form casting defect is one of the drawbacks. Technological expectations due to increasing performance and environmental requirements diminish the tolerance for defects. Shrinkage porosity is one of the most frequent defects in cast materials including lamellar cast iron. During solidification of lamellar cast iron, the main solidifying phases are the austenite and the graphite. Precipitated austenite has a higher density compared to liquid iron, while graphite has a lower density. The combined effect of precipitation will be a volume decrease due to the austenite precipitation and a volume increase due to the graphite precipitation. The overall volume change will be dependent on the solidification kinetics and the mixture of the austenite and graphite phases.

Formation mechanisms of the shrinkage porosity are still unclear in spite of the large efforts invested in the research of this topic. Relation between the solidification kinetics and the volume change during solidification is believed to influence the shrinkage porosity formation. Several experimental techniques have been developed to measure the volume change and observe the

Department of Mechanical Engineering/Component Technology, PO Box 1026, Jönköping 55111 , Sweden

*Corresponding author, email svidropeter@gmail.com solidification kinetics at the same time with the scope to identify the shrinkage formation mechanisms.

An extensive literature survey has been performed to follow the development of volume change measurement techniques. Furthermore a brief summary of advances in the interpretation of solidification kinetics are presented, which are believed to have an influence on the read of results from volume change measurements. Based on a known experimental layout, a new set-up has been developed as multiaxial volume change measurement combined with expansion forces measurement.

The aims of the present paper are to identify the problems at volume change measurements and to point out advantages and drawbacks of different measuring techniques.

\section{Literature review}

\section{Methods for measuring volume changes}

Study of the literature with respect to measuring techniques of volume change in metals and especially cast iron indicates two major measuring methods. One method is the measurement of the volume change directly. The second is the measurement of the linear displacement of the sample in one or several directions at the same time. Volume change is then calculated on the basis of the displacement data. This way, the second method is considered as an indirect measuring method. Both methods have been introduced approximately side by side from a historical point of view. Important additional methods have been connected later to extend the understanding of the volume change. These methods were the temperature measurement and the expansion force measurements. 

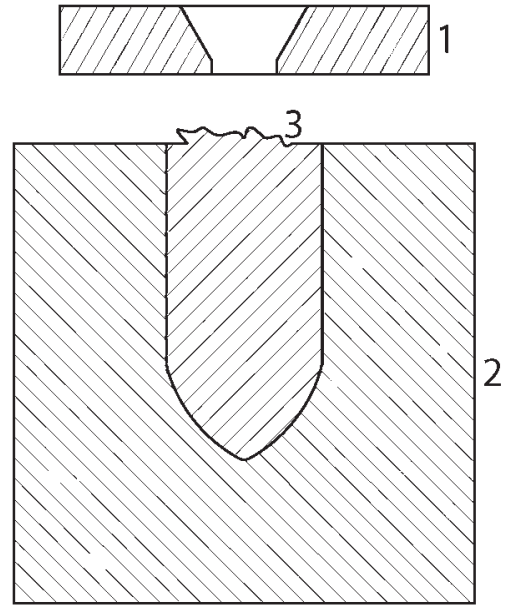

1. gate
2. mold
3. projectile

1 Projectile and mould made of cast iron (figure redrawn of original by author)

\section{Direct measurements of volume change}

Réaumur seems to be the first to state cast iron expansion during cooling in $1722 .^{1}$ Since evidences existed on various degrees, not much attention was taken on the phenomena until the 1860s. An observation was made at Royal Arsenal Woolwich on lengthwise cast projectiles from cast iron (Fig. 1). After pouring through a narrow neck, this gate has been removed right after the mould was filled. As it starts to solidify, liquid was pressed out at the break.

The first noted experiment on volume changes with a series of investigations was implemented in $1874^{2}$ by Mallet. In the absence of proper equipment, he used the comparison of volume and density of water and cast iron poured into a conical vessel (Fig. 2). A research programme in the beginning of the 1950 s presented a new experimental process to track shrinkage during solidification. In this approach, volumetric changes during solidification have been analysed with the use of specially designed riser combined with a furnace (Fig. 3) developed by Taylor et $a l^{3}$ The riser was preheated before casting and heated during solidification to be able to keep the melt in the riser molten. Lamellar cast iron was cast into the green sand mould, and a graphite bobber was placed on the melt surface in the

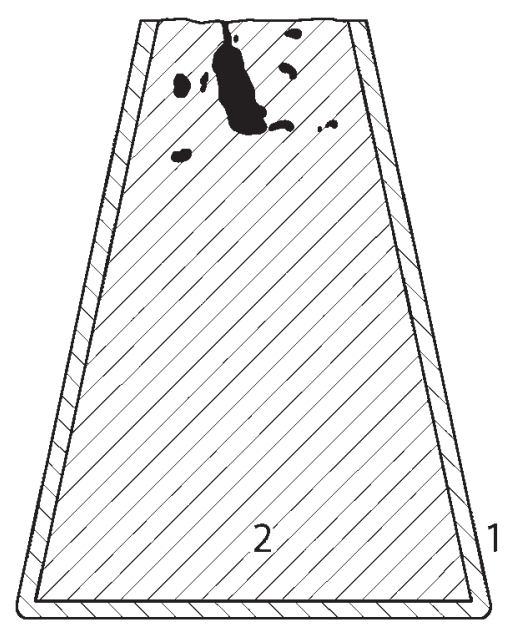

1. vessel
2. specimen

2 Mallet's conical vessel (figure redrawn of original by author)

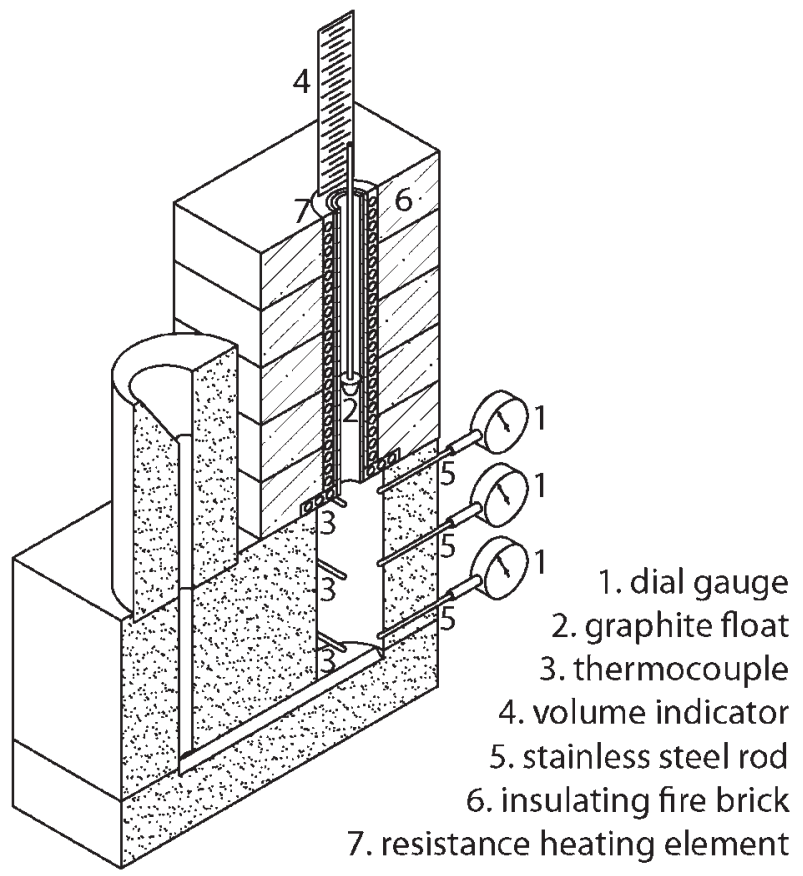

3 Schematic of pycnometer by Schmidt-Taylor (figure redrawn of original by author)

riser. Along with temperature measurement, movement of the bobber and displacement from the dial gauges built in the mould wall were registered every $30 \mathrm{~s}$ until complete freezing. The weakness of this layout is the uncertain effect of the gating system and also the unverifiable float of the bobber, which may distort the final results.

In the middle of the decade, Tatur introduced his geometry for shrinkage measurement (Fig. 4). ${ }^{4}$ This is a permanent mould made of two cones linked together and casted from the top through the round opening.

The geometry of the sample promotes the formation of shrinkage porosity in the upper part of the sample in connection to the top surface where the metal is poured into the mould cavity. Volume of the shrinkage porosity is measured by dropping liquid into the shrinkage cavity. The drawback of this method is the lack of information during solidification. In addition, a

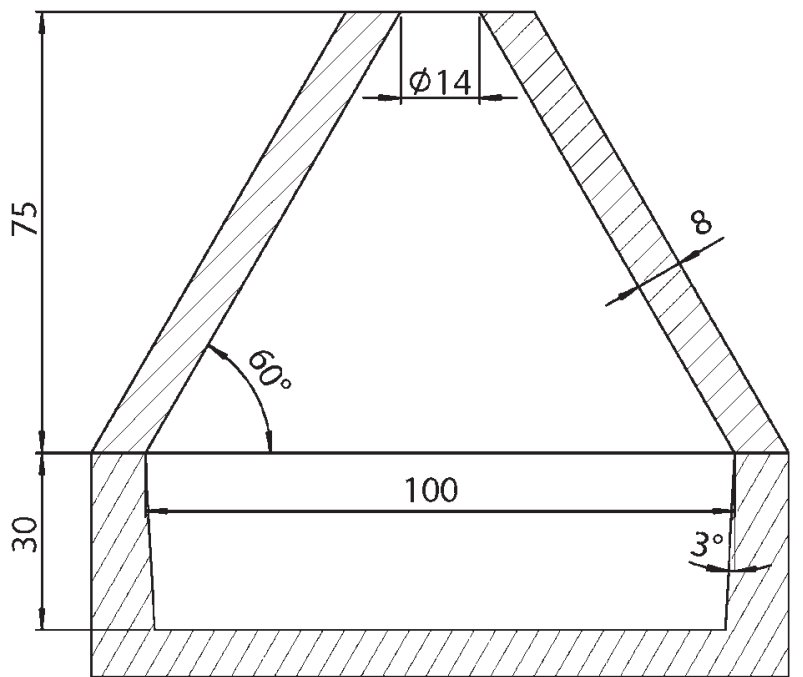

4 Tatur probe (figure redrawn of original by author) 


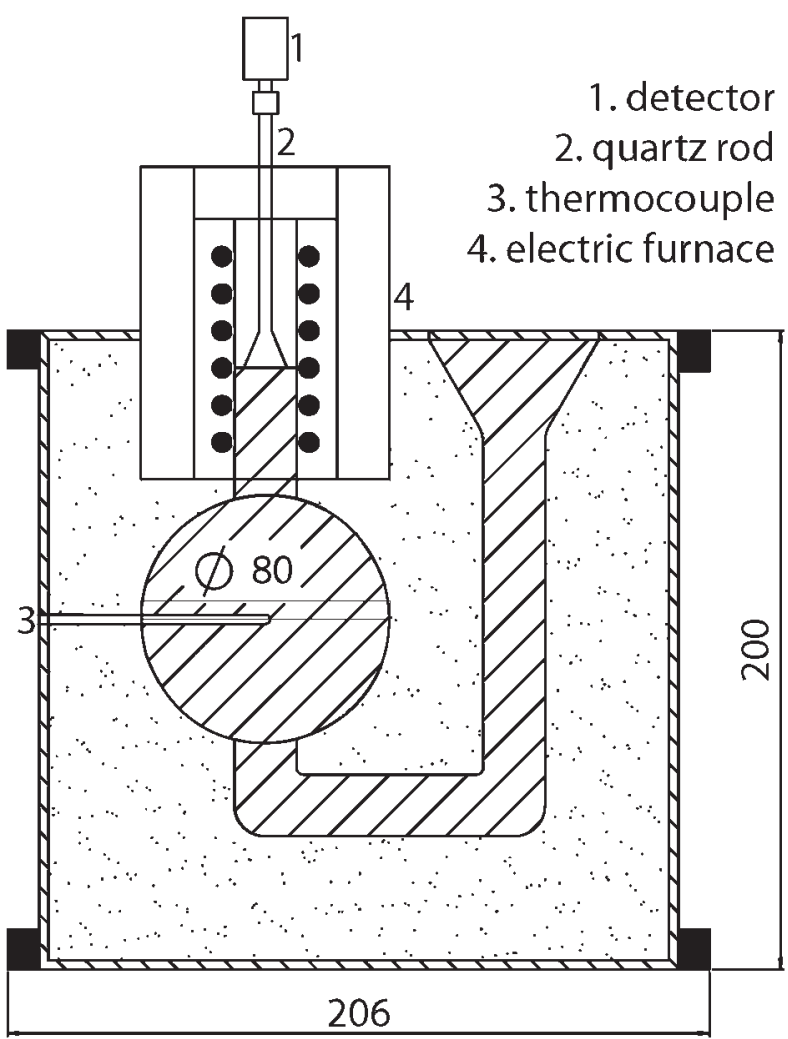

5 Direct measurement on spherical geometry (figure redrawn of original by author)

weakness that cast metal has to fill up the mould cavity exactly, shrinkage porosity can be identified on room temperature by being filled with liquid aimed for measurement. An accurate measurement is difficult because measuring liquid cannot enter all the capillaries due to surface tension.

In 1992, Yang and Alhainen made volumetric investigations on globular castings ${ }^{5}$ in the similar layout like that of Schmidt et al. One of the innovative values of their work was the usage of spherical geometry since sphere is more even than other previous specimen from the thermal point of view. Moreover, they also solved the problem of the effect of the gating system by sectioning it from the casting with a quartz bar.

Latest investigations by direct measurements are also using the spherical geometry (Fig. 5) made by Zou et al. ${ }^{6}$ However the sphere shape was promising, the effect of the riser and tracking of the melt level were not solved reassuringly.

\section{Indirect measurement of volume change based on linear displacement}

In 1886, F. Osmond presented a new way to observe the volumetric changes. ${ }^{7}$ The metallic sample was

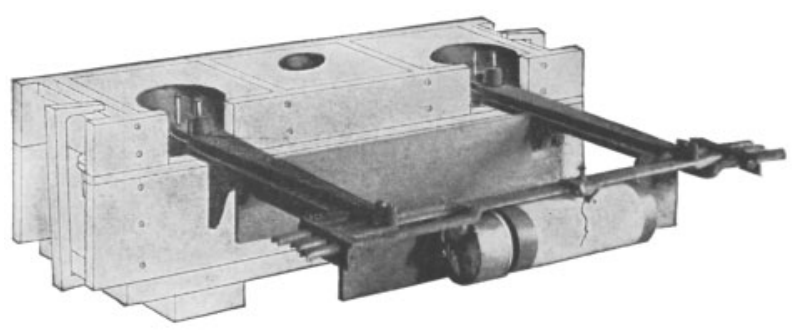

6 Keep's cooling curve recording machine

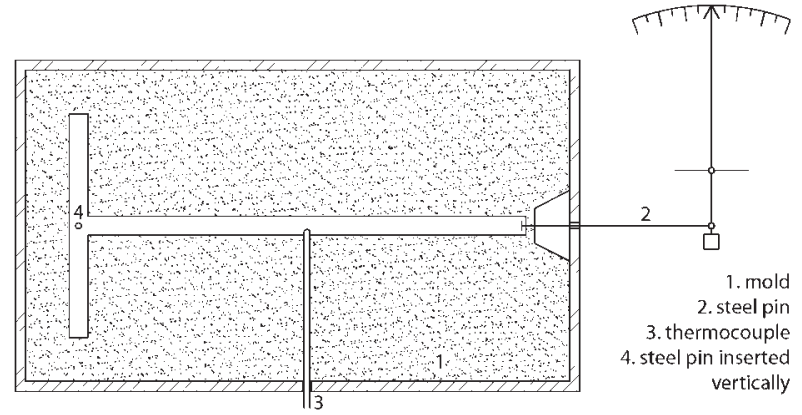

7 Turner's set-up (figure redrawn of original by author)

introduced into a ceramic cylindrical container with two pistons on each end. One of the pistons was constrained, and the other was transmitting the axial linear deformation. This type of displacement can be classified as unidirectional displacement. Introducing Le Chatelier's recently developed electric pyrometer, Osmond created a measuring device comparable to today's dilatometer. ${ }^{8}$

The first equipment able to register displacement in two directions during the entire cooling interval, from the liquid state down to room temperature, was developed in $1895^{9}$ by Keep, and it was called cooling curve recording machine (Fig. 6). Using sand mould, a $1 / 2 \times 1 / 2 \times 12$ in bar was created between two parallel surfaces of a yoke probe. The yoke has been embedded previously into the mould, and steel pins were inserted vertically in the ends. Displacement was registered on a paper drum rotated by a clock with pen attached to levers trough hinges connected to the moving pins. Since the displacements were measured in two directions, the used experimental method is considered as multidirectional measurement.

As a next step, temperature measurement was brought up by Turner. ${ }^{10}$ Here, he registered a displacement-time and a temperature-time curve on a $\mathrm{T}$ shape test bar (Fig. 7). The top of the ' $T$ ' section was expected to solidify quicker than the rest of the casting, constraining the longitudinal deformation of the specimen in the mould. In addition, a steel pin through the mould was inserted in the cross to secure position. By this way, the displacement was forced into one direction, so this layout can be classified as unidirectional measurement.

The revolutionary set-up of the era in the means of the shape of the specimen as a cylinder was introduced by Wüst. ${ }^{11}$ Using a bar (Ф30, $1350 \mathrm{~mm}$; Fig. 8), the movements were collected along the longitudinal axis, so this can be considered as the first single axis, multidirectional measurement. Although it used a hydraulic system, further variants by West ${ }^{12}$ and Diefenthäler ${ }^{13}$ have been developed to transmit displacement.

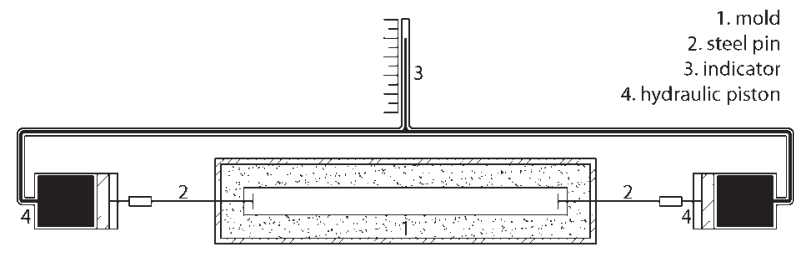

8 Wüst's arrangement (figure redrawn of original by author) 


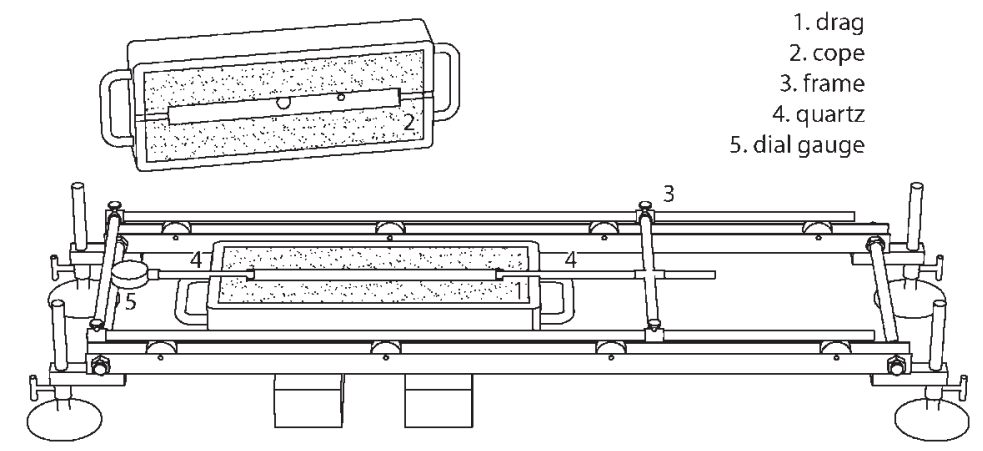

\section{Shrinkage measurement equipment by Bardenheuer and Bottenberg (figure redrawn of original by author)}

In 1922, Sauerwald introduced his arrangement depending on buoyancy, but later, he also turned into the linear layout. ${ }^{14}$

The initiation of quartz rod instead of steel pins was an important improvement of Wüst and Schitzkowski. ${ }^{15}$ The advantage of using quartz is the low thermal expansion and thermal conductivity of the quartz improving the accuracy of the measurement. Moreover, registering device can be installed next to the mould neglecting complicated mechanics used for transmitting the movement. Despite the benefits of quartz, there was contradiction of its usage. Sauerwald performed an investigation similar to Wüst's experimental arrangement to observe the effect of the mould movement. It was performed with an angular specimen $(3 \times 3 \times 350 \mathrm{~mm})$ of lead ${ }^{16}$ and confirmed the expedience of the quartz rods. Another experiment made by Bardenheuer and Ebbefeld on a $\Phi 80 \mathrm{~mm}$ spherical casting concluded that warming of the sand is not influential on the expansion, ${ }^{17}$ questioning the usefulness of quartz rods; even so, Bardenheuer together with Bottenberg shifted to quartz (Fig. 9). ${ }^{18}$ The final version used horizontally casted cylindrical test bar in a sand mould. The layout was a displacement register with quartz rod on one end and a quartz rod on the other end fastened to a movable frame around the mould. By movement of the frame, the contradirectional displacements were collected and summarised. The melt was poured into the mould through the vertical gate at the middle of the specimen, while temperature and displacement of the quartz rods were registered.

Linear dilatation measurements came back in focus in 1960 by Nándori. ${ }^{19}$ Remarkable work have been carried out both on linear shrinkage ${ }^{20}$ and expansion. ${ }^{21} \mathrm{He}$ also investigated the changes in length during solidification on white and grey cast iron. ${ }^{22}$ As a novelty tool, pressure measurement was joined into the solidification experiments. $^{23}$
The next step was the introduction of thermal analysis into this field by Stefanescu et $a .^{24} \mathrm{~A}$ measurement apparatus called DTASV have been created from a thermal analysis cup made of croning sand (Fig. 10). The differential analysis of the cooling curve gives a new interpretation of the solidification as a function of the linear displacement.

A simplified version of the linear set-up showed up in 1983 with a unidirectional interpretation by Gazda and Zemlak. $^{25}$

In the beginning of the 1990s, Yang and Alhainen used the modified adaptation of the linear arrangement to predict microstructure in spheroidal graphite iron $^{26}$ on a cylindrical and later also on a cube geometry. $^{27}$

In 1995, Gedeonova et al. extended the vertical bar arrangement by measuring the radial displacement and expansion force. A rigid metallic shell was placed around the mould aimed to study the influence of mould stability on the shrinkage and dilatation (Fig. 11). ${ }^{28}$ Further development of the volume change measuring technique was carried out by introducing QuiK-cup sample holders known from thermal analysis measurements by Mrvar et $a l$. Quartz rods have been added to a QuiK-cup to register multidirectional linear deformation in addition to the temperature measurement (Fig. 12). ${ }^{29}$ Among many advantages, one drawback of this set-up is the thermal instability of the QuiK-cup, since the thermal centre moves away from the thermocouple with the migration of the hot spot as it was highlighted by Diószegi and Svensson. ${ }^{30}$

On the millennium, a new arrangement of the unidirectional linear measurement was presented with sectioning the runner from the cylindrical specimen by Mutwil. $^{31}$

Mrvar et al. in 2002 created an upgrade of the QuiKcup, now measuring also the movement and the temperature of the mould (Fig. 13). ${ }^{32}$

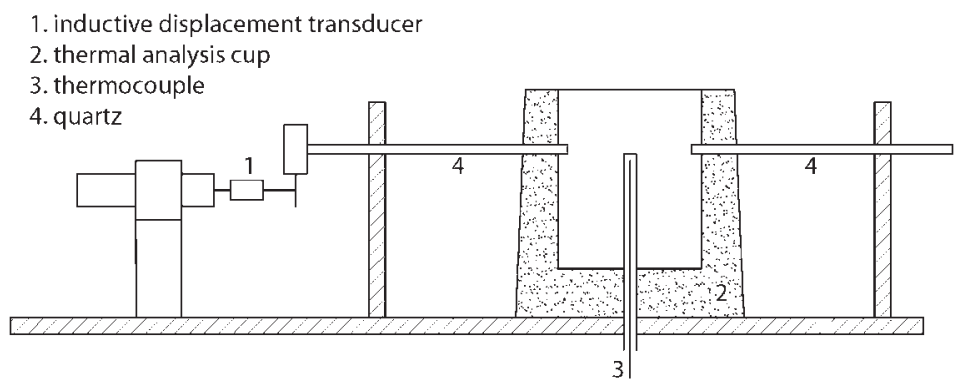




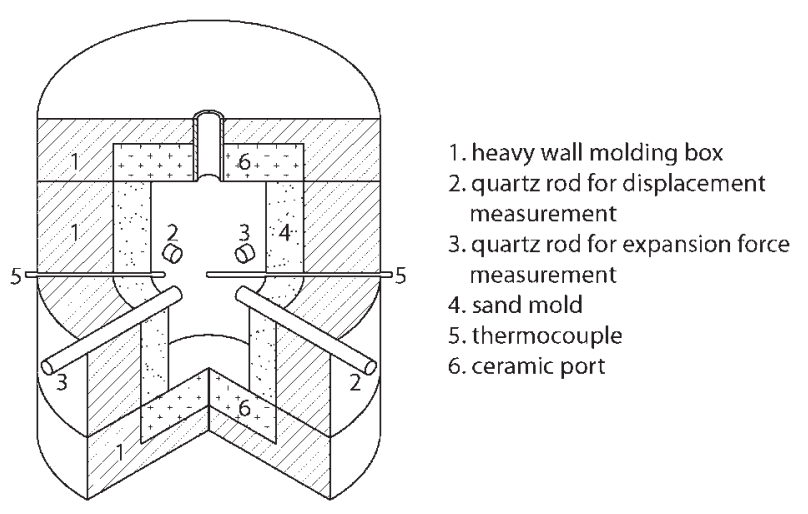

11 Vertical arrangement for measurement of shrinkage and dilatation on cylindrical sample (figure redrawn of original by author)

A new version of Mutwil's device appears in 2009 to measure shrinkage and stresses in vertical arrangement. ${ }^{33}$ As the most recent experiments, in 2011, Chisamera et al. have used $200 \mathrm{~mm}$ length and $30 \mathrm{~mm}$ square crosssection bar in the unidirectional layout to study shrinkage evaluation in ductile iron (Fig. 14). ${ }^{34}$ In 2012, an improved version of this experimental layout called cooling and contraction/expansion curve analyser has been published. The top opened ceramic cup is a shell mould including a thermocouple and a contraction/expansion measuring device. ${ }^{35}$ Moreover, in this year, another experimental instrument has been introduced called a liquid to solid dilatometer. This layout consist of a cylindrical sample in a sodium silicate sand mould enclosed into a steel frame. ${ }^{36}$ Both cooling and contraction/expansion curve analyser and liquid to solid dilatometer can be classified as single axis unidirectional measurement.
Since dilatometry is a distinct measuring technique, this paper will not go into deep details of this technique and will only show the metallurgical aspects briefly. This analysis is generally used to measure linear displacement against temperature and calculate volume change based on the linear displacement. Three different distinct techniques are known for registration of displacement: the capacitive, the optical and the push rod method. The most common method is the push rod type: specified size of sample is placed into a ceramic cylinder with ceramic pistons in the ends, and a surrounding furnace provides the requested temperature. Displacement of the pistons is registered by a displacement sensor (usually linear variable differential transformer). The push rod, the cylindrical sample and the pistons are made of graphite, sapphire or polycrystalline alumina to keep a low linear expansion not to disturb the measured results.

The drawback of the method appears when the linear displacement is recalculated to volume change. The interaction between the outer surface of the metallic sample and the inner surface of the ceramic cylinder implicates measurement bugs. If the diameter of the metallic sample extends the inner diameter of the ceramic cylinder due to thermal expansion, the expansion forces of the metal can overload the cylinder leading to the crack of the measurement chamber. If the metallic sample becomes liquid before the metal is in contact with the cylinder, the cylindrical chamber will be not filled adequate due to the surface tension difference between the ceramic and the molten metallic material. The advantage of the dilatometer is the excellent control of the temperature and the even thermal distribution inside the chamber. Registration of the displacement is very accurate; optical components provide touchless measurement.

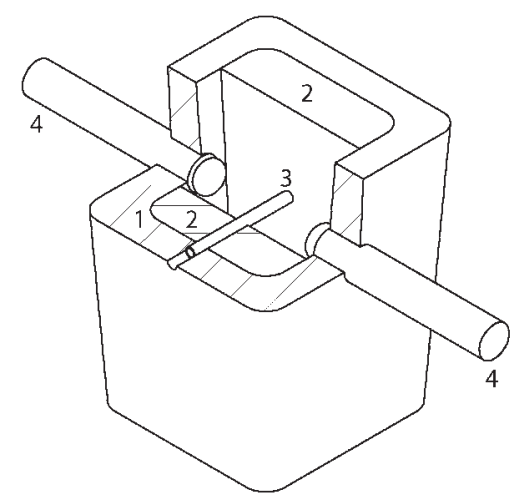

\author{
1. standard quick-cup \\ 2. sand inlay made by $\mathrm{CO} 2$ treatment \\ 3. thermocouple NiCr-Ni in a quartz tube
}

4. quartz rod

12 Displacement measurement on QuiK-cup (figure redrawn of original by author)

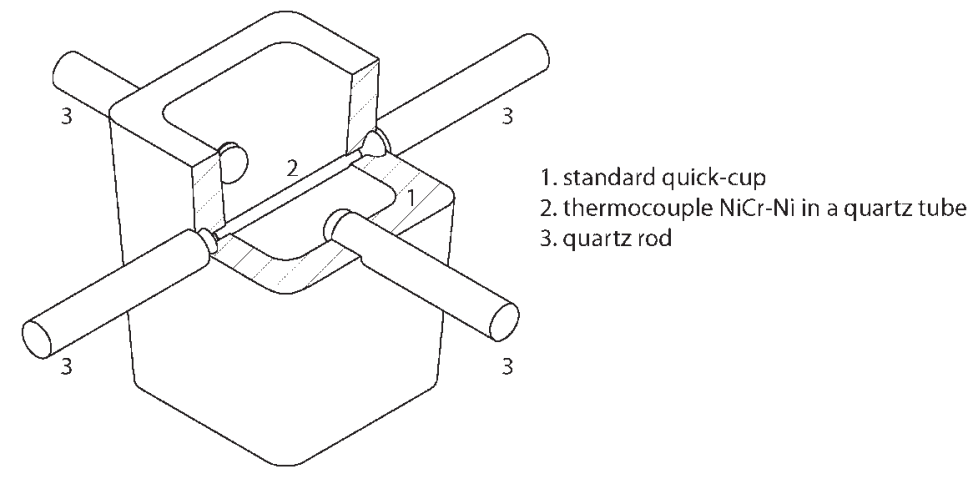




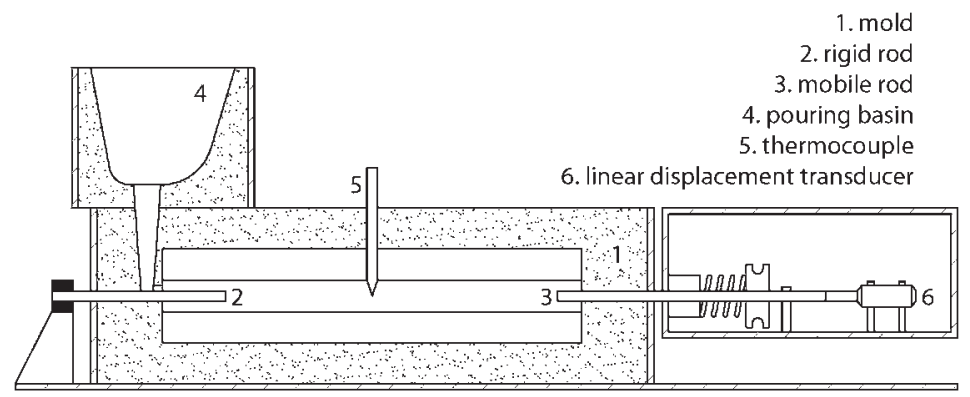

Expansion and shrinkage of both lamellar and spheroidal graphite iron were investigated on a new level by a laser dilatometer. ${ }^{37}$ However, the accuracy of this technique is better than the previous solutions; the method limits the size of the sample weighting $\sim 90 \mathrm{~g}$.

\section{Important advances in characterisation of macrostructure and its influence on interpretation of volume change measurements}

Discrepancies in volume change of samples cast under similar conditions by different scientists were not understood before a series of new methods were introduced in characterisation of the macrostructure and microstructure of the cast iron. Direct austempering after solidification was introduced by Rivera at al., ${ }^{38}$ making it possible to distinguish the primary austenite grains formed during solidification. Under as cast condition, the austenite grains are decomposed in pearlite/or ferrite grains during the steady state transformation and become not distinguishable on microprobes. Applying direct austempering after solidification, the cast iron sample is shaken out at $950^{\circ} \mathrm{C}$ for heat homogenisation and a following quenching in salt bath below the solid state transformation temperature preserve the crystallographic orientation of the primary austenite grains. Furthermore, Diószegi at al. ${ }^{39}$ distinguished the primary grains formed on the mould wall

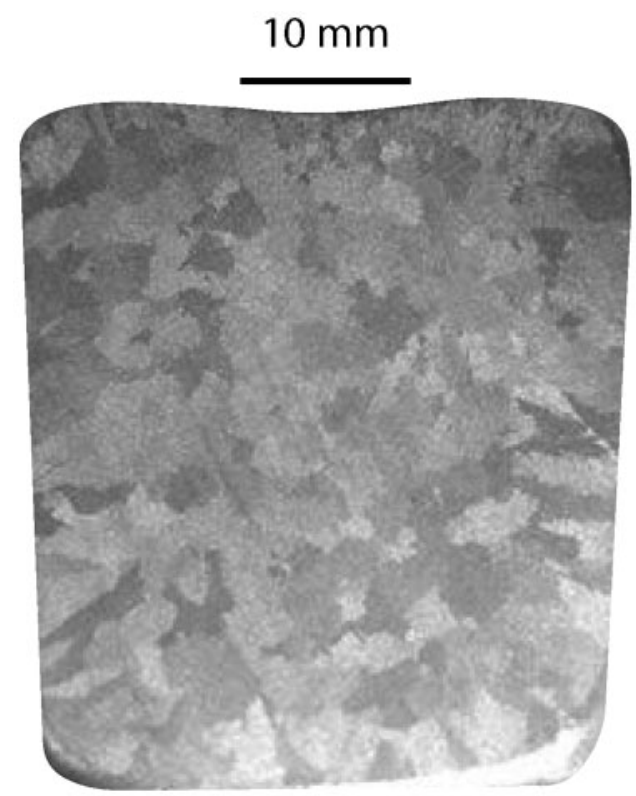

15 Direct austempering after solidification treated QuiKcup sample revealing primary austenite grains in hypoeutectic grey cast iron and thus formed in the liquid. The grains nucleated on the mould wall belongs to the columnar zone and are called 'casting skin' in popular foundry men language. The grains nucleated in the liquid belong to the equiaxed zone (see Figs. 15 and 16).

The development and collaboration between the columnar and equiaxed zone are influenced among others by the austenite grain nucleation and by the cooling condition. A large number of nucleated equiaxed grains suppress the thickness of the columnar zone, or contrary, the low number or the absence of equiaxed grains promotes the thickness of the columnar zone.

Colour etching was important because it reveals all components of the microstructure, including graphite morphology and eutectic cells, and also distinguishes the pearlite original from primary or eutectic austenite on the same image. Colour etching was introduced in cast iron investigation during the last two decades by Rivera at $a l^{40}$ and disseminated in several publications by Diószegi $^{41}$ (see Figs. 17 and 18).

\section{Experimental}

Summarising the experiences on volumetric measurements, a detailed experiment set-up was designed. The scope of the measurement was to find relation between

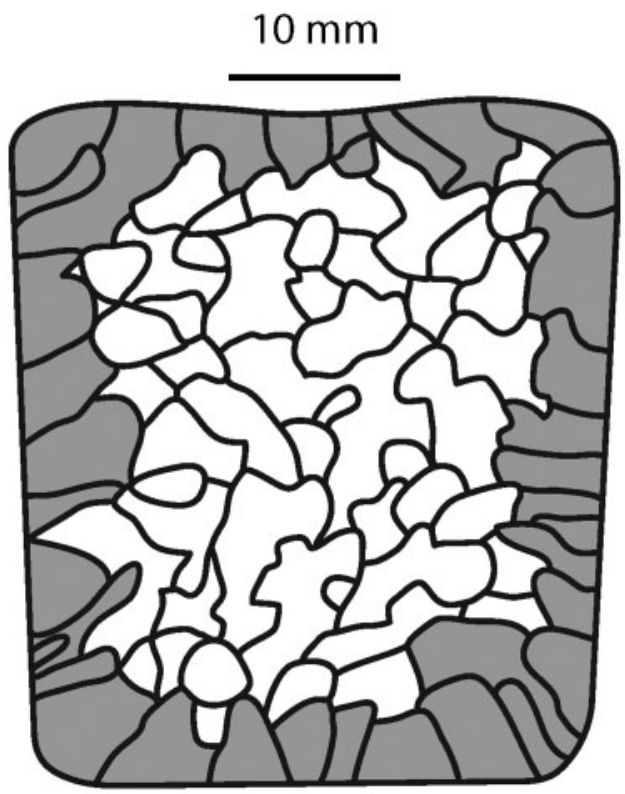

16 Redrawn primary austenite grain boundaries from sample in Fig. 15 where columnar zone is coloured in grey and equiaxed zone is white 


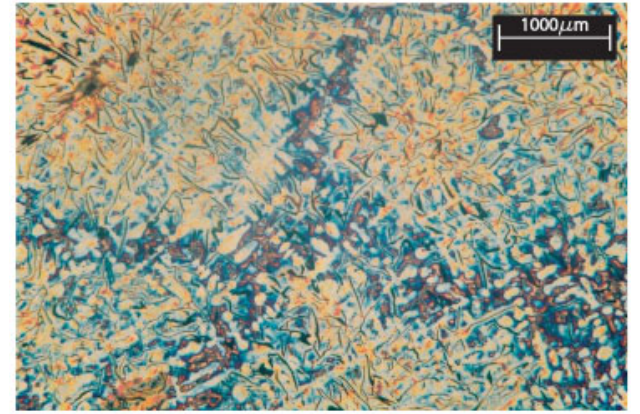

17 Eutectic cells including lamellar graphite are embedded in dendritic network

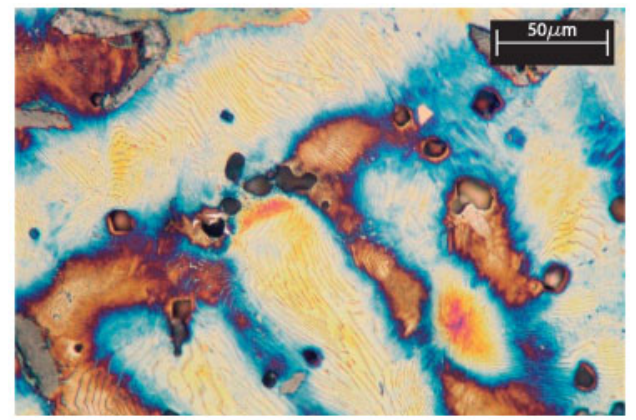

18 Light coloured pearlite matrix solidified as primary austenite versus dark coloured pearlite matrix solidified as eutectic austenite before steady state transformation

the volume changes based on linear displacement and expansion force. The innovation of this measurement was the introduction of the multiaxis and directional linear displacement measurement, along with the twothermocouple thermal analysis method in combination with the measurement of expansion forces. Two cylindrical samples of $\Phi 50$ and length $350 \mathrm{~mm}$ were cast parallel from the same alloy. The samples were moulded in a shell sand mould. Dimensions of the drag and cope was $45 \times 100 \times 407 \mathrm{~mm}$. One of the moulds was aimed for the displacement and the temperature measurement. Two thermocouples of type ' $\mathrm{S}$ ' (PtPtRh10) were placed perpendicular to the longitudinal axis of the cylindrical casting. The measuring spot of the thermocouple was placed in the thermal centrum equivalent with the cylinders rotational axis $T_{\mathrm{C}}$ respectively displaced $10 \mathrm{~mm}$ from the axis to the cylindrical surface $T_{\mathrm{S}}$. The temperature sensors were protected by a quartz tube [ $\Phi 5$ external and $\Phi 3$ internal diameter ( $\mathrm{mm})$ ] welded at the end to a hemisphere and a $1 \mathrm{~mm}$ thick protecting wall. Two quartz rods $(\Phi 10 \mathrm{~mm})$ were built in the mould's parting line coinciding with the axis of the cylinder, aimed to transmit the axial linear displacement of the test bar. Two more quartz rods were built in the mould's parting line perpendicular to the cylinders rotational axis aimed to transmit the radial linear displacement of the test bar. The mould with the quartz rods and the displacement sensors were assembled by a special frame on a table.

The second mould aimed for expansion force measurement was equipped only with two $(\Phi 10 \mathrm{~mm})$ quartz rods built in the mould's parting line coinciding with the axis of the cylindrical specimen. In this case, the quartz rods connected to a force measuring unit were assembled also by a special frame on a table. The experimental assembly is shown in Fig. 19. Two heats of lamellar cast iron were prepared in a $60 \mathrm{~kg}$ medium frequency induction furnace using returns of commercial casting components. After melting, the iron was heated to $1460^{\circ} \mathrm{C}$, held at the maximum temperature for $20 \mathrm{~min}$ and transferred to a preheated $40 \mathrm{~kg}$ hand ladle for casting. Different level of Sr based commercial inoculant was added into the stream $(0.05$ and $0.15 \mathrm{wt}-\%)$. The temperature in the ladle just before pouring was $1440^{\circ} \mathrm{C}$. The chemical composition is shown in Table 1.

The signals from temperature, displacement and force measurement were captured by an HBM-Beam U10 software system.

The circular cross-section of the cylindrical samples $85 \mathrm{~mm}$ from the end surface has been prepared for colour etching and investigated with respect to the microstructure. The average eutectic cell size was measured within a circular area with radius $15 \mathrm{~mm}$ in

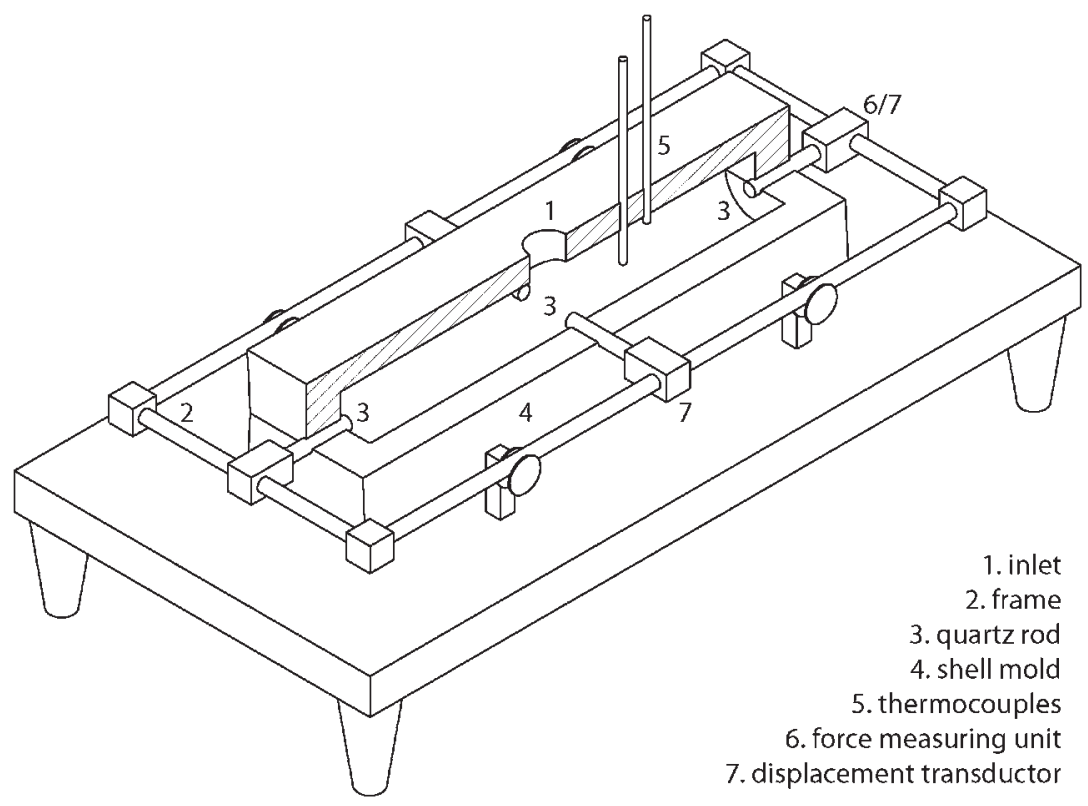




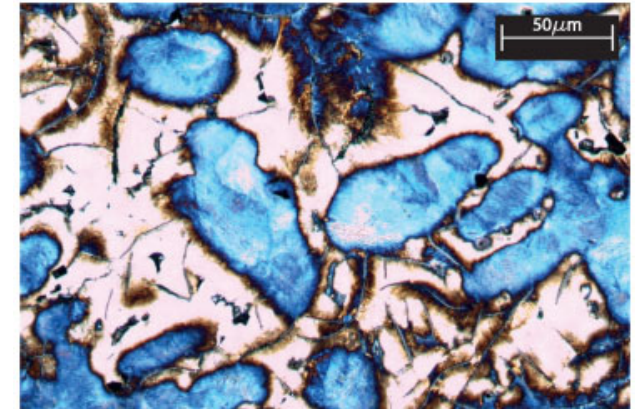

20 Dendritic network from the area between eutectic cells, heat

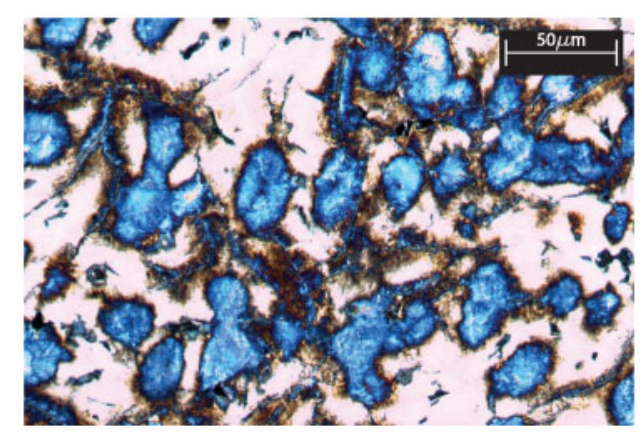

21 Dendritic network from the area between eutectic cells, heat II

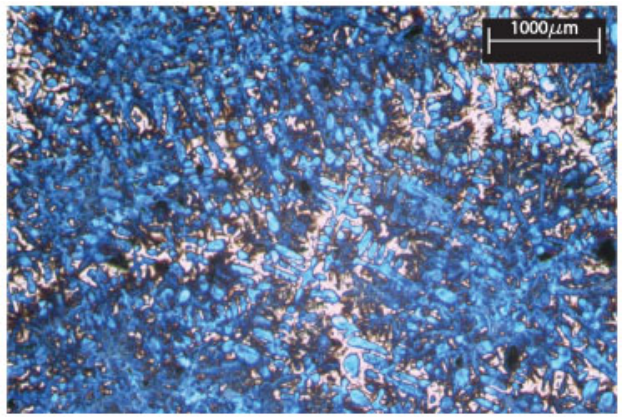

Eutectic cells engulfing the dendrite network, heat I

the middle of the analysed cross-section. The investigated circular area is supposed to belong to the equiaxed zone with respect to the macrostructure. The obtained eutectic cell size was $1396 \mu \mathrm{m}$ for heat I and $1572 \mu \mathrm{m}$ for heat II. The surface area fraction of the primary austenite was measured in selected areas between the eutectic cells Figs. 20 and 21. According to Figs. 22 and 23 , the eutectic cells engulf the dendrite network, and the segregation pattern and the colour interference obtained after etching make it difficult to exactly distinguish the dendritic network. The statistical distribution of the dendritic network is supposed to be even in the equiaxed zone, while areas between the eutectic cells are chosen to distinguish the dendrites more exactly from the

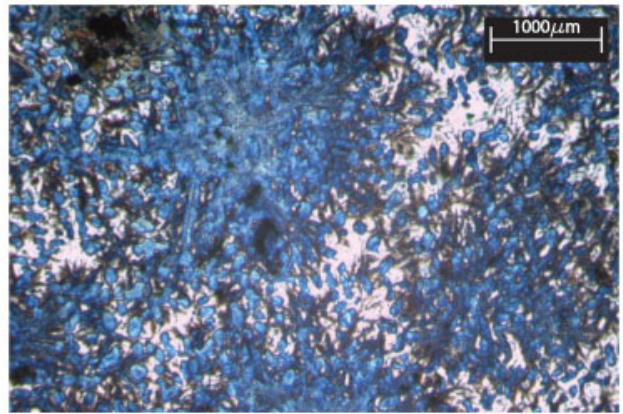

23

Eutectic cells engulfing the dendrite network, heat II

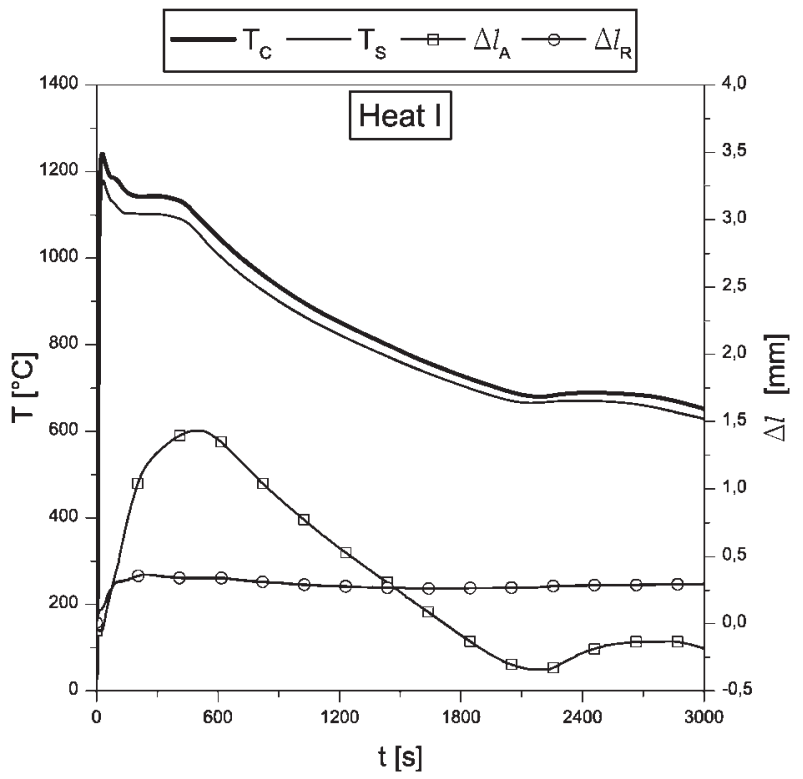

24 Cooling and displacement curves registered in heat I

surrounding matrix. The average primary austenite surface fraction measured on samples was 0.32 in heat I and $0 \cdot 3$ in heat II.

\section{Results and discussion}

The obtained results from the reported experiments are discussed with respect to the literature data collected in Chapter $2 \cdot 1$, where the characteristics of the macrostructure are invoked to interpret the observed linear and radial displacement. The collected temperature and force measurement data are used to support the interpretation.

\section{Problem of early linear expansion}

The linear axial $\Delta l_{\mathrm{A}}$ and linear radial $\Delta l_{\mathrm{R}}$ displacements as a function of time $t$ are presented on the same diagram as the temperature in the central $T_{\mathrm{C}}$ and the temperature in the lateral $T_{\mathrm{S}}$ thermocouple versus time $t$ in Figs. 24 and 25. The starting point of the process was defined at the moment when the measured temperature starts to increase over the ambient temperature. This

Table 1 Chemical compositions

\begin{tabular}{|c|c|c|c|c|c|c|c|c|c|c|c|}
\hline & $C$ & $\mathrm{Si}$ & $\mathrm{Mn}$ & $P$ & $S$ & $\mathrm{Cr}$ & Mo & $\mathrm{Cu}$ & Sn & V & $\mathrm{Ni}$ \\
\hline Heat I & 3.516 & $1 \cdot 811$ & 0.590 & 0.051 & 0.106 & 0.154 & $0 \cdot 246$ & 0.889 & 0.048 & 0.014 & 0.062 \\
\hline Heat II & 3.510 & $1 \cdot 849$ & 0.541 & 0.052 & 0.090 & $0 \cdot 152$ & 0.242 & 0.888 & 0.046 & 0.013 & 0.088 \\
\hline
\end{tabular}




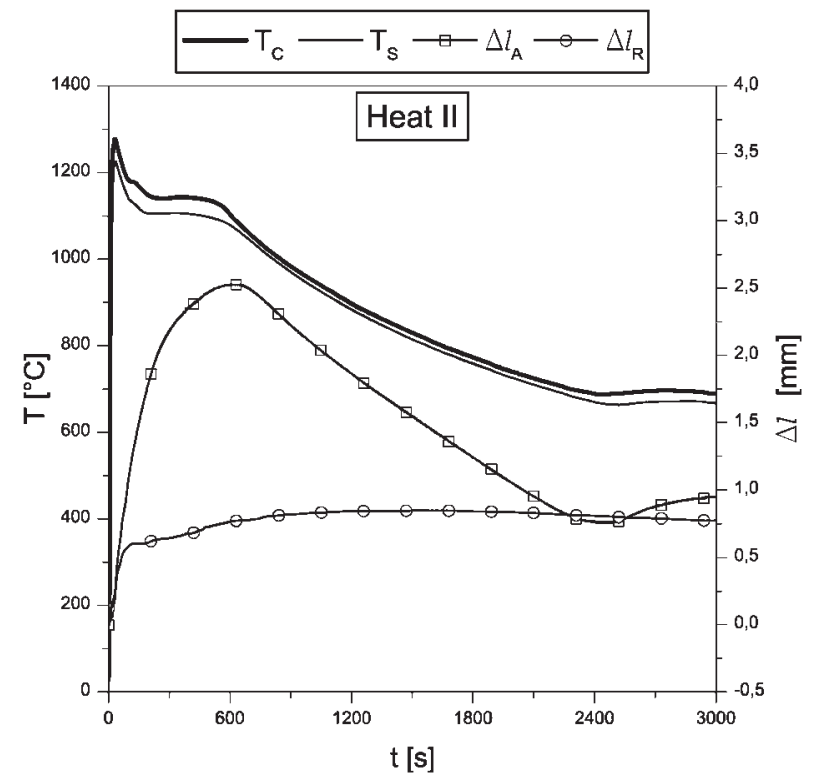

25

Cooling and displacement curves registered in heat II

moment is supposed to correspond to the time when the liquid iron reaches the thermocouple situated in the parting line where the horizontally placed cylindrical bar is filled up to the half. The measured cooling curves are similar between the experimental heats with small differences with respect to the main characteristic points. The measured displacement shows significant different characteristic shapes for the linear axial and the linear radial displacement. The displacement in axial direction $\Delta l_{\mathrm{A}}$ starts when the central thermocouple reaches the maximum temperature with an expanding motion and reaches the expansion limit when temperature passes the inflection point of the central thermocouple, indicating the end of solidification for both heats. The displacement in radial direction $\Delta l_{\mathrm{R}}$ starts also when the central thermocouple reaches the maximum temperature with an expanding motion but continue the expansion until different moments of the solidification depending on the experimental heat. At heat I, the expansion limit is reached already after $200 \mathrm{~s}$ corresponding the maximum recalescence during the eutectic solidification indicated in the central thermocouple. At heat II, the expansion limit is reached after $1600 \mathrm{~s}$ corresponding a temperature of $830^{\circ} \mathrm{C}$ in the central thermocouple.

The presence of the early linear expansion displacement in both axial and radial direction could be explained by the relation to the metallostatic pressure appearing in the liquid iron created by the level differences between the quartz rod and the top of the downsprue after mould filling. The duration of the metallostatic pressure responsible for the expansion displacement depends on how long the top of the downsprue and the quartz rods are interconnected with liquid metal. This moment corresponds to a local coherence of the primary austenite network interrupting the liquid communication. From the start of the columnar zone formation until the columnar to equiaxed transition (CET) the casting skin can be considered a container with continuously changing container thickness surrounded with the mould material. Inside the container, equivalent with the casting skin by definition, there is a shrinking mixture of liquid metal and floating equiaxed crystals. Depending on the thickness

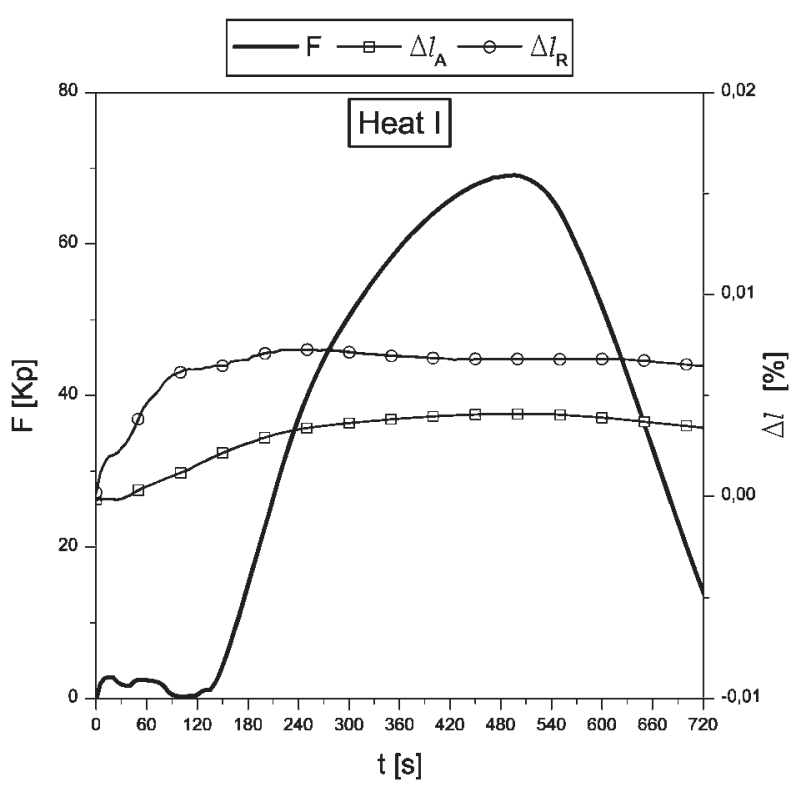

26 Accumulated force and displacement curves registered in Heat I

and the strength of the columnar zone, the size and shape of the theoretic container are expected to interact with the thermally loaded mould material resulting in both volume and shape change, hence resulting in the measured early linear displacement. The observations related to the registered early expansion indicate the weakness of the measuring method using connecting rods to transmit displacement between the mould cavity and the displacement sensor.

\section{Expansion and shrinkage measurements combined with expansion force measurement to identify CET}

The CET is the moment when the equiaxed crystals imping and fill up the space inside the columnar zone, creating a continuous, coherent crystal network. From this moment, the coherent crystal frame is supposed to be able to withstand compressive load and become less dependent on the mould wall movement. The measurement results presented in Figs. 26 and 27 represent the expansion forces $F$ accumulated during solidification together with the linear axial and linear radial displacement as a function of time.

From the start of the measurement, there is a relative low force fluctuation as a function of time, which corresponds to the observed axial linear expansion where the expansion movement of the quartz rods was related to the metallostatic pressure and the deformation of the casting skin under influence of the thermally loaded mould. Owing to the arrangement of the experimental equipment aimed to measure expansion force, the used quartz rods are leaned to the surface of a force measuring unit constraining any linear expansion. An increase in the accumulated forces would be only possible if the quartz rods are supported by a solid network with a corresponding compressive toughness. Consequently, the start of the continuous increase in expansion forces corresponds to the presence of the coherent crystal frame supporting the quartz rods to transduce the force on the measuring unit. In other words, the start of the continuous increase in the expansion force indicates the CET. The exact moment 


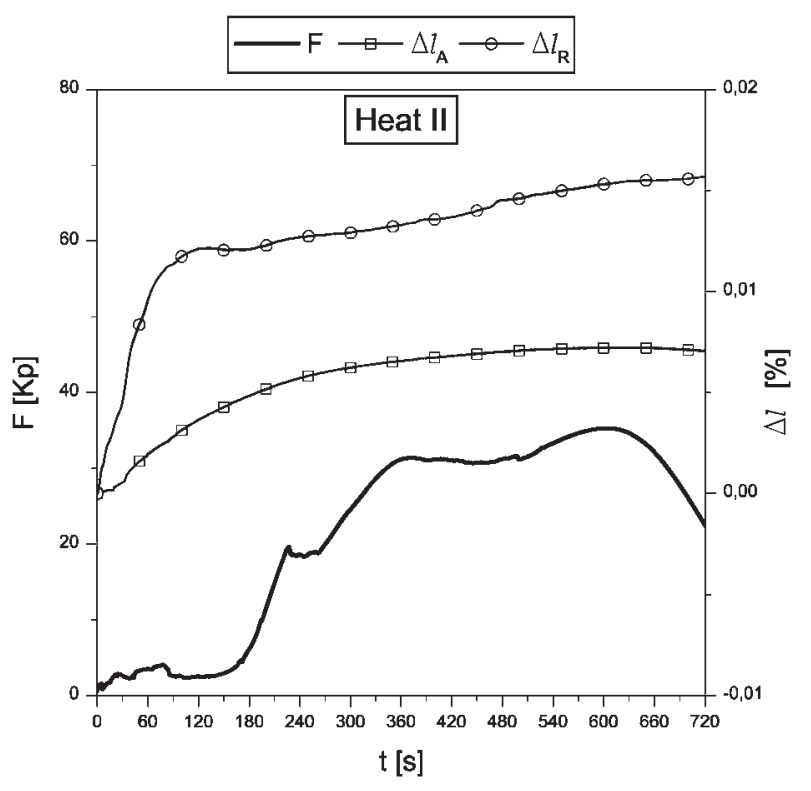

27 Accumulated force and displacement curves registered in heat II

of the CET was found at $100 \mathrm{~s}$ for experimental heat I and $139 \mathrm{~s}$ for experimental heat II.

The source for the expansion force and the expansion displacement is considered the precipitation of the graphite starting first in the columnar zone and continuing in the equiaxed zone. The lateral thermocouple $T_{\mathrm{S}}$ away from the cylindrical axis, placed closest to the columnar zone, indicates the temperature associated to the start of graphite precipitation at $120 \mathrm{~s}$ at heat I and at $170 \mathrm{~s}$ at heat II.

Fluctuations observed later under the solidification process of heat II are shown in Fig. 27, where the accumulation of the expansion force stagnates should be possible only with the failure of the crystal network. The expansion forces exceed the compressive strength of the crystal network causing the stagnation. The presented interpretation of the cooling conditions together with displacement and force accumulation measurements makes it possible for a novel definition for the location of CET.

\section{Anisotropic volume change during solidification and cooling}

Comparison of linear axial and the linear radial displacement within the same heat is presented in Figs. 28. and 29. The linear axial displacement is related to the axial length $(350 \mathrm{~mm})$, and the linear radial displacement is related to the radial diameter $(50 \mathrm{~mm})$. The difference between the linear axial and the linear radial movement indicates the anisotropy of the displacement. The radial displacement is larger than the axial. The radial displacement is a result of the interaction between the internal equiaxed grains, the cylindrical mantle of the columnar zone and the moulding material. The axial displacement is more complicated because in addition to the moulding material and the equiaxed grains, the axial deformation of the columnar mantle is influenced by the columnar zone forming a disc shaped zone at both ends of the cylinder. The equiaxed grains are expected to have a random orientation, which should have an equally distributed influence on the total radial

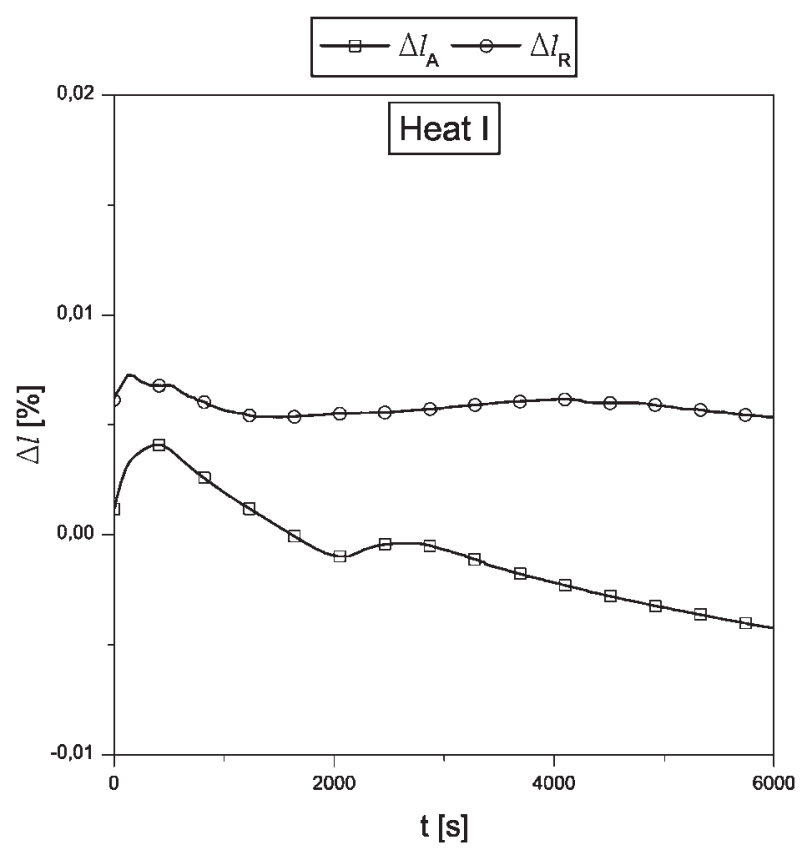

28 Linear axial and linear radial displacement versus time in heat I

and axial displacement. The existence of the disc shaped columnar zone at the ends of the cylinder my hinder the displacement during both expansion and shrinkage.

The anisotropic character of the volume change can explain the observation presented in chapter $4 \cdot 1$ where the expansion limit for radial direction in heat II was reached beyond the solidification time and beyond the maximum accumulated pressure registered by the force measuring unit. This type of anisotropy indicates the possibility of plastic deformation when the axial shrinkage is counteracted by the radial expansion possible due to the low tensile strength of the columnar mantle.

A consequence of the anisotropy can be seen on the calculated volume changes based on the measured

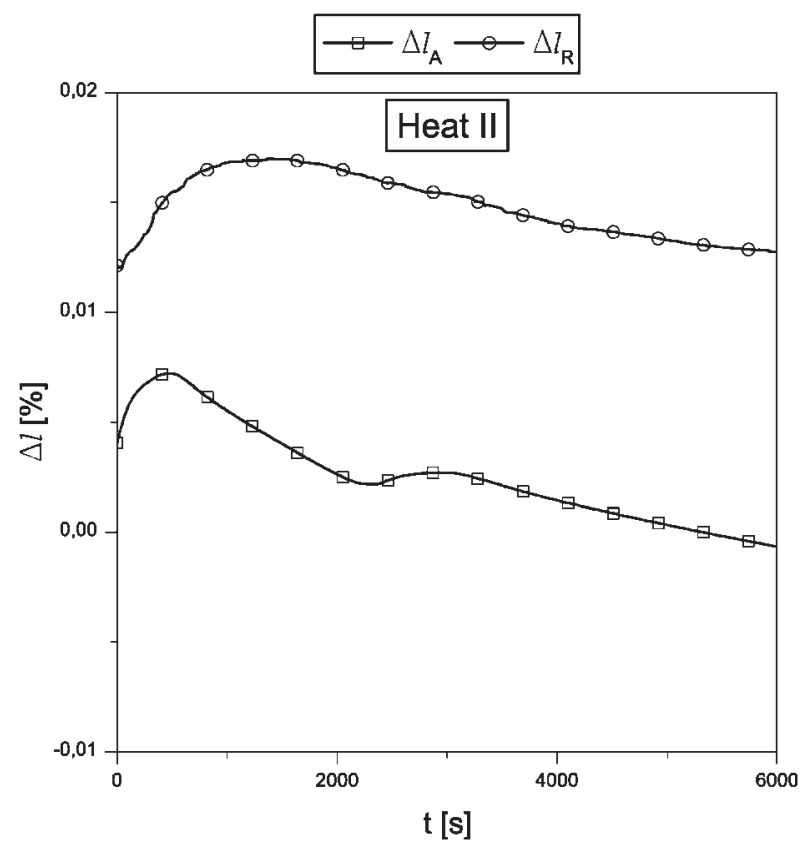

29 Linear axial and linear radial displacement versus time in heat II 


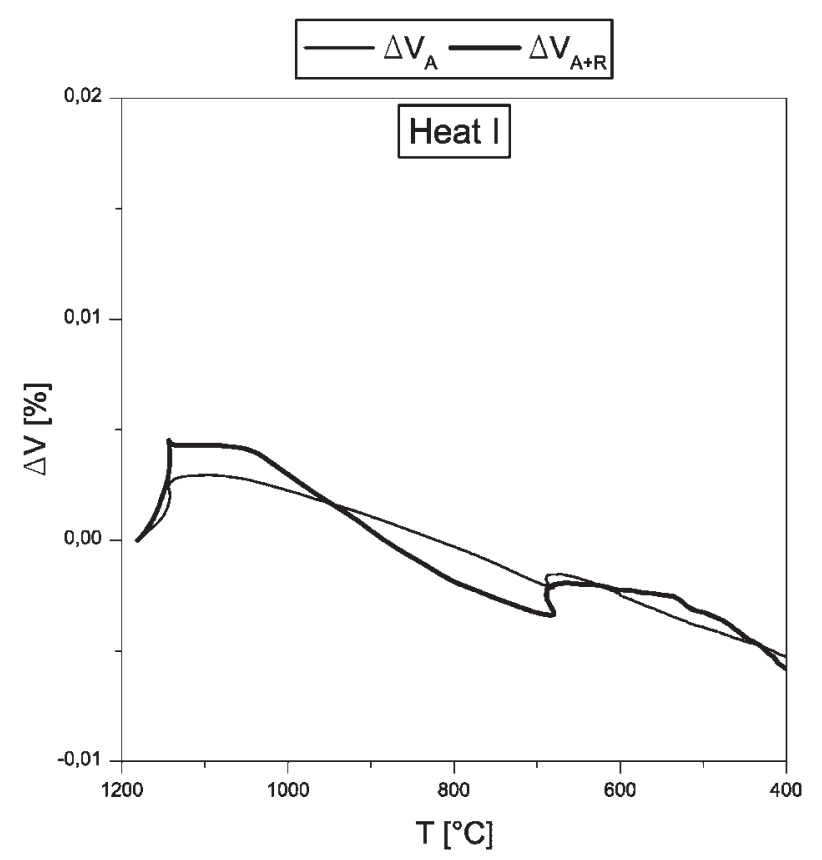

30 Volume change based on axial displacement versus volume change based on axial and radial displacement in heat I

displacement. Figures 30 and 31 show the calculated volume change based only on the axial displacement $\Delta V_{\mathrm{A}}$ compared to the calculated volume change based on both the measured axial and radial displacement $\Delta V_{\mathrm{A}+\mathrm{R}}$. Displacement values detected before CET have been subtracted from the data series. The volume change is calculated from the moment where the CET is defined based on the force measurement described in the previous chapter.

\section{Summary}

An extensive literature study of direct and indirect volume change measurement techniques has been presented. Literature on advances in the interpretation of the solidification with respect to the primary austenite grains has also been included to support the discussion of phenomena appearing during volume change at solidification of lamellar cast iron. Summarising the literature, an indirect method including multidirectional measuring arrangements has been tested. The axial and radial displacements in cylindrical samples have been completed with temperature and expansion force measurement. Measured results just like results found in the literature indicated an early expansion in both axial and radial direction. These expansions are related to the interaction between the moulding material, the columnar zone forming a container like solid shell and the mixture of liquid and equiaxed crystals. Introduction of a force measuring unit refines the interpretation of the solidification by indicating when the CET takes place. A continuous force increment observed on the force measuring unit is related to the existence of a coherent dendrite network in the equiaxed zone supporting the load on the instrument. Comparison of the registered axial and radial linear deformation indicates an anisotropic volume change in cylindrical samples. The volume change anisotropy should be influenced by the size of the columnar zone and reveal the problems with the classical

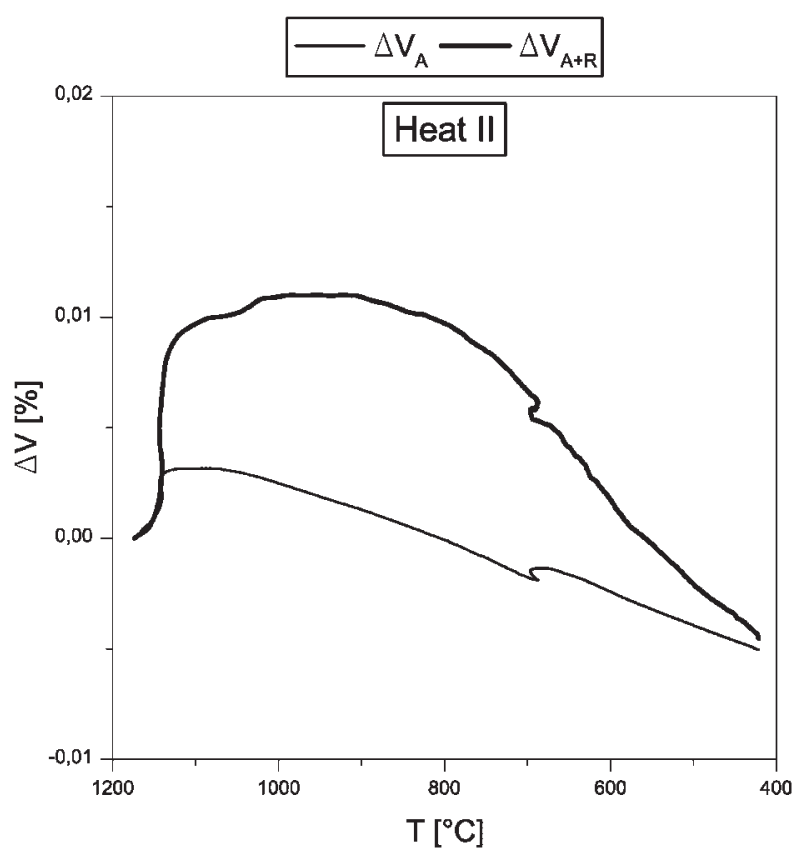

31 Volume change based on axial displacement versus volume change based on axial and radial displacement in heat II

measurement of linear expansion or shrinkage measured in only one direction. Small differences in the metallurgical behaviour, by adding different amounts of inoculants, caused also differences in the obtained and calculated volume changes. The study of the influences from metallurgical parameters on the volume change during solidification will be the next topic to be presented.

\section{Acknowledgements}

The experimental part of the present work has been carried out within a collaboration project between Volvo Powertrain AB, Sweden and the Foundry Department at University of Miskolc, Hungary. The analysing part of this work has been performed within the JÄRNKOLL 2C project financed by the Swedish Knowledge and Competence Foundation in collaboration between the School of Engineering at Jönköping University, Volvo Powertrain AB and Scania CV AB. All contributors are acknowledged.

\section{References}

1. R.-A. F. de Réaumur: 'Memoirs on steel and iron', Chez Michel Brunet, Paris, France, 1722.

2. R. Mallet: 'On the alleged expansion in volume of various substances in passing by refrigeration from the state of liquid fusion to that of solidification', Proc. R. Soc. London, 1874, 23, 209-234.

3. W. A. Schmidt, E. Sullivan and B. F. Brown: 'Risering of gray iron castings', Trans. Am. Foundrymen Soc., 1954, 62, 70-77.

4. A. Tatur: 'La solidification des alliages légers, étude de la retassure', Fonderie, 1955, 116, 4681-4693.

5. Y. Yang and J. Alhainen: 'Estimation of the tendency towards shrinkage in spheroidal-graphite iron melts using thermal analysis', Cast Met., 1992, 5, (2),73-77.

6. Y. Zou, Y. Hayashi, H. Kojima, K. Yamazaki and H. Nakae: 'Influence of mold material and ce value on shrinkage of spheroidal graphite cast iron', Proc. 70th World Foundry Cong., Monterrey, Nuevo Leon, Mexico, WFO, April 2012. Paper 11.

7. F. Osmond: 'Sur les phénomenes qui se produisent pendant le chauffage et le refroidissement de l'acier fondu', Comptes Rendus, 1886, ciii, (743), 1135. 
8. F. Osmond: 'On the critical points of iron and steel', J. Iron Steel Inst., 1890, 1, 38-80.

9. W. J. Keep: 'Cooling curves and test for cast iron', J. Iron Steel Inst., 1895, 2, 227-248

10. T. Turner: 'Volume and temperature changes during the cooling of cast iron', J. Iron Steel Inst., 1906, 1, 48-74.

11. F. Wüst: 'Die Schwindung von Metallen und Metalllegierungen', Metallurgie, 1909, 6, 769-792.

12. T. D. West: 'Metallurgy of cast iron', Cleveland Print. \& Publishing Company, Cleveland, USA, 1902.

13. A. Diefenthäler: 'Die Ursachen der Lunkerung und ihr Zusammenhang mit Schwindung und Gattierung', Stahl und Eisen, 1912, 32, (II), 1813-1819.

14. K. Bornemann and F. Sauerwald: 'Dichtemessungen von Metallen und Legierungen', Z. Metallkd., 1922, 14, 145-159.

15. F. Wüst and G. Schitzkowski: 'Einfluß einiger Fremdkörper auf die Schwindung des Eisens', Mitteilungen aus dem Kaiser-WilhelmInstitut für Eisenforschung zu Düsseldorf, 1992, 4, 105-124.

16. F. Sauerwald: 'Über die Gesetzmässigkeiten der Volumengestaltung und Schwindung von Metallen und Legierungen', Giesserei-Zeitung, 1923, 20, 391-393.

17. P. Bardenheuer and C. Ebbefeld: 'Beitrag zur Analyse des Schwindungsvorganges von weißem und grauem Gußeisen', Mitteilungen aus dem Kaiser-Wilhelm-Institut für Eisenforschung zu Düsseldorf, 1926, 6, 45-60.

18. P. Bardenheuer and W. Bottenberg: 'Einfluß der Schmelzbehandlung auf den Gasgehalt und die Schwindung von weißem und grauem Gußeisen', Mitteilungen aus dem KaiserWilhelm-Institut für Eisenforschung zu Düsseldorf, 1931, 13, 149159.

19. G. Nándori: 'Measurement of the volumetrical and linear shrinkage of gray-iron and testing some shrinkage affecting facors', Kohászati Lapok, Öntöde, 1960, 11, 241-247.

20. G. Nándori: 'A szürke öntöttvas vonalas zsugorodására jellemző adatok vizsgálata', Kohászati Lapok, Öntöde, 1964, 4, 73-77.

21. G. Nándori: 'Az öntöttvas eutektikus duzzadásának hatása az öntvény pórusosságára', Bányászati és Kohászati Lapok, Öntöde, 1968, 2, 5-11.

22. G. Nándori: 'Szürke és fehér töretü öntöttvasak térfogatváltozásainak viszgálata a dermedés folyamán', Bányászati és Kohászati Lapok, Öntöde, 1973, 10, 217-224.

23. G. Nándori and P. Jónás: 'A tágulási erő mint az öntöttvasak és acélok minőségi jellemzője a kristályosodás folyamán’, Bányászati és Kohászati Lapok, Öntöde, 1988, 12, 169-173.

24. D. M. Stefanescu, L. Dinescu, S. Crăciun and M. Popescu: 'Production of vermicular graphite cast-irons by operative control and correction of graphite shape.', Proc. 46th Int. Foundry Congress, CIATF, Madrid, Spain, WFO, October 1979, 37-37/15.

25. A. Gazda and E. Zemlak: 'Apparatus for measurement of dimensional changes of solidifying casting alloys', Pr. Inst. Odlew., 1983, 33, (2-3), 159-173.
26. Y. Yang and J. Alhainen: 'Microstructure estimation of SG iron with a dilatometer', Proc. CASTCON'91, Institute of British Foundrymen, 1991, IBF, Harrogate, UK, 1-14.

27. Y. Yang and J. Alhainen: 'Functional improvement of dilatation analysis on thermal analysis for S. G. iron quality estimation', Proc. 5th Int. Symp. on 'Physical metallurgy of cast iron', Nancy, France, October 1994, Trans Tech Publications, Ltd., 568.

28. Z. Gedeonova, S. Bodi, J. Dúl, G. Nándori and L. Vigh: 'Displacement on the surface mould and metal during the solidification of nodular graphite iron castings', Mater. Sci. Forum, 1995, 2, (215-216), 391-398.

29. P. Mrvar, M. Trbižan and J. Medved: 'Investigation of cast iron solidification with dilatation analysis', Kovine Zlitine Tehnologije (Slovenia), 1999, 33, (1-2), 45-49.

30. A. Diószegi and I. L. Svensson: 'On the problems of thermal analysis of solidification', Mater. Sci. Eng. A, 2005, A413-A414, 474479

31. J. Mutwil: 'Device for the investigation of casting stresses', Solidification Met. Alloys, 2000, 2, (44), 503-508.

32. P. Mrvar, M. Trbižan and J. Medved: 'Examination of dimensional changes of casting and mould during the solidification of modified and unmodified aluminium cast alloys', Proc. of the 11th International Metallurgical \& Material Conference METAL 2002, Hradec nad Moravicí, Czech Republic, Tanger, May 2002, $1-8$.

33. J. Mutwil: 'Design changes of device to investigation of alloys linear contraction and shrinkage stresses', Arch. Foundry Eng., 2009, 9, (4), 149-156.

34. M. Chisamera, I. Riposan, S. Stan, P. Toboc, T. Skaland and D. White: 'Shrinkage evaluation in ductile iron as influenced by mould media and inoculant type', Int. J. Cast Met. Res., 2011, 24, (1), 28-36.

35. M. Chisamera, I. Riposan, S. Stan and M. Barstow: 'Simultaneous cooling and contraction/expansion curve analysis during ductile iron solidification', Trans. Am. Foundrymen Soc., 2012, 120, 375388

36. D. M. Stefanescu, M. Moran and S. Boonmee: 'Use of combined liquid displacement and cooling curve analysis in understanding the solidification of cast iron', Trans. Am. Foundrymen Soc., 2012, 120, 365-374.

37. A. Kagawa, S. Kiguchi and M. Osada: 'Volumetric change in freezing cast irons', Trans. Am. Foundrymen Soc., 1995, 14, 18-23.

38. G. L. Rivera, R. E. Boeri and J. A. Sikora: 'Solidification of gray cast iron', Scr. Mater., 2004, 50, (3), 331-335.

39. A. Diószegi, K. Z. Liu and I. L. Svensson: 'Inoculation of primary austenite in grey cast iron', Int. J. Cast Met. Res., 2007, 20, (2), 68 72, , 2007.

40. G. L. Rivera, R. E. Boeri and J. A. Sikora: 'Revealing solidification structure of nodular iron', Cast Met., 1995, 8, (1), 1-5.

41. A. Diószegi: 'On the microstructure formation and mechanical properties in grey cast iron', Dissertation no. 871, Linköping Studies in Science and Technology, Linköping, Sweden, 2004. 